\title{
Laboratory investigations on the survival of marine bacteriophages in raw and treated seawater
}

\author{
K. Moebus \\ Biologische Anstalt Helgoland (Meeresstation); D-W-2192 Helgoland, Federal Republic \\ of Germany
}

\begin{abstract}
Laboratory investigations were performed to gain insight into the mechanisms which govern the survival of marine bacteriophages in nature. Samples collected in 1988 to 1990 at station "Kabeltonne" near Helgoland were used raw, membrane-filtered $(0.15 \mu \mathrm{m})$, and/or after inverse filtration through $10 \mu \mathrm{m}$-mesh gauze to reduce or increase live and dead particles. The development of natural or artificial bacterial populations and the survival of 2 to 10 distinguishable strains of test phage were followed during incubation at $20^{\circ} \mathrm{C}$. The results obtained with most test phages point to the predominant role of indigenous bacteria for marine phage inactivation which was generally enhanced by sample managements leading to improved growth of bacteria. The virucidal properties of the samples differed greatly in total strength as well as in the changes taking place during incubation, the latter resulting in conspicuously differing inactivation curves. Generally, phage inactivation was slow during the first 2 to 3 days of incubation, followed by a period of very rapid inactivation which usually coincided with the die-away of colony-forming bacteria. This period lasted either only a few days or until the concentration of test phage was reduced to (near) zero. While the inactivation of most test phage is assumedly caused by proteolytic enzymes released during the die-away of bacteria, the survivability of one test phage (H7/2) was also markedly influenced by the bacteria sensitive to it. Survival rates of the test phages in the laboratory tests were generally of the same order of magnitude as those recently observed with natural phage populations.
\end{abstract}

\section{INTRODUCTION}

An extensive literature, reviewed by Kapuscinski \& Mitchell in 1980 and ever increasing since then, exists concerning the survivability in seawater of enteric viruses and some non-marine bacteriophages, but almost no information is available on marine phages. This situation clearly results from the interest focussed on enteric viruses for sanitary reasons, with non-marine phages serving as easier-to-handle model systems (Mitchell \& Jannasch, 1969; Bitton \& Mitchell, 1974; Berry \& Noton, 1976; Kapuscinski \& Mitchell, 1983) or as presumed pollution indicators (Kott, 1966; Kott \& Ben Ari, 1968; Niemi, 1976). In contrast, marine phages have for more than 30 years following their detection (Spencer, 1955) been all but ignored, although their existence poses an, at least scientifically, highly interesting problem: that of host-parasite systems surviving in sparsely populated environments. There are only two reports dealing with bacteriophages derived from estuarine environments (Ahrens, 1971; Zachary, 1976), but none regarding phage-host systems (PHS) found in off-shore waters.

Numerous factors have been found to affect the survivability of the viruses investigated; however, often contradicting observations were reported in regard to specific 
factors. To mention only one example, most authors reported autoclaving and filtration to be very effective in removing antiviral activity of seawater, while Akin et al. (1976) with regard to poliovirus I observed only minor changes after such sterilizations in the virucidal activity of samples taken from Mobile Bay (Alabama, USA). Nevertheless, a prominent role must be ascribed to marine microorganisms, especially to bacteria (Gundersen et al., 1967; Magnusson et al., 1967; Fujioka et al., 1980; Toranzo et al., 1982; Ward et al., 1986; Kamei et al., 1987). Findings of Zachary (1976) also point to the involvement of microorganisms in the inactivation of the two estuarine phage strains used by the author. Other factors of major interest in regard to marine phages are sunlight, temperature, and adsorption to particles other than host bacteria.

This investigation was performed with the aim of developing and evaluating methods suited to deal with the problem of maintenance of marine phage-host systems in nature.

\section{MATERIALS AND METHODS}

Media: Seawater agar (SWA), soft seawater agar (sSWA) and full strength seawater bouillon (SWB) were prepared according to the 2216E formula of Oppenheimer \& ZoBell (1952): $5 \mathrm{~g}$ peptone (Difco), $1 \mathrm{~g}$ yeast extract (Difco), and $0.01 \mathrm{~g} \mathrm{FePO}_{4}$ per liter of seawater mixture (SM, $75 \%$ aged seawater plus $25 \%$ distilled water), with $15 \mathrm{~g}$ agar (Difco) added for SWA and $6 \mathrm{~g}$ agar for sSWA. Reduced strength seawater bouillon (SWB/5) contained $1 \mathrm{~g}$ peptone and $0.2 \mathrm{~g}$ yeast extract per liter, but was otherwise identical with SWB. SM was used as diluent in titrations. For special purposes, aged seawater was enriched with 0.5 to $2 \mathrm{ml}$ of SWB $1^{-1}$ before sterilization: ASW(e). For stronger nutrient enrichments $25 \times$ SWB was employed, being of 25 -fold concentration in peptone and yeast extract as compared to SWB. Beef extract solution ( $3 \%$ in distilled water) was used for washings of Sartorius fibre filters only. The media were sterilized by autoclaving for $20 \mathrm{~min}$ at $121^{\circ} \mathrm{C}$. When necessary, $\mathrm{pH} 7.6$ in media was adjusted by addition of $10 \%$ $\mathrm{NaOH}$ prior to autoclaving.

Seawater collected at station "Kabeltonne" (between Helgoland and the adjacent island resort Düne) from about $1 \mathrm{~m}$ depth was used untreated (raw seawater, RSW), after filtration through $0.2 \mu \mathrm{m}$ Nucleopore or $0.15 \mu \mathrm{m}$ Sartorius cellulose-nitrate filters (filtered seawater, FSW), and after various other forms of treatment which will be referred to in the "Results". As soon as possible, each sample was tested for the concentration of colony forming bacteria (CFU) and for the presence of phages infective for the host bacteria of test phages used in the respective experiment.

With FSW inexplicable observations were made during 1988 to 1990 . To avoid virucidal substances which might wash off fibre filters (Hidaka \& Ichida, 1972), it was decided to use Nucleopore membranes. When the FSW produced with such a filter was found to be contaminated with a few types of bacteria mainly producing small colonies, the use of Nucleopore filters was given up at once. All of the following FSW samples were prepared with Sartorius fibre filters which had never before failed to give sterile filtrates except when aged seawater was filtered. To avoid inimical substances possibly washing out from the filters, the first $150 \mathrm{ml}$ of filtrate were discarded. Without any change in method, all FSW samples prepared in this way in 1988 and 1990 were found to be contaminated but, surprisingly, only one of those prepared in 1989. CFU contaminating 
FSW samples, comprising up to , but mostly less than, 10 types of CFU, produced, with few exceptions, colonies of less than $1 \mathrm{~mm}$ in diameter under standard conditions.

Test phages: From high titre phage stocks, each containing at least $10^{9}$ plaqueforming units (PFU) $\mathrm{ml}^{-1}$ of the strains listed in Table 1, mixtures of varying composition were prepared so that, upon inoculation of the experimental samples, an initial titre of

Table 1. List of test phage strains and host bacteria employed in this investigation

\begin{tabular}{|c|c|c|}
\hline $\begin{array}{l}\text { Phage } \\
\text { strain }\end{array}$ & $\begin{array}{l}\text { Bradley } \\
\text { group }\end{array}$ & $\begin{array}{l}\text { Host } \\
\text { strain }\end{array}$ \\
\hline $\mathrm{H} 2 / 1$ & A & $\mathrm{H} 2$ \\
\hline $\mathrm{H} 3 / 1$ & A & $\mathrm{H} 3$ \\
\hline $\mathrm{H} 4 / 4$ & $\mathrm{C}$ & $\mathrm{H} 4$ \\
\hline $\mathrm{H} 6 / 1$ & $\mathrm{C}$ & H 6 \\
\hline $\mathrm{H} 7 / 2$ & $\mathrm{~A}$ & $\mathrm{H} 7, \mathrm{H} 71 \cdots$ \\
\hline $\mathrm{H} 11 / 1$ & $\mathrm{~A}$ & $\mathrm{H} 11$ \\
\hline $\mathrm{H} 17 / 1^{*}$ & $\mathrm{C}$ & H17epe \\
\hline $\mathrm{H} 24 / 1$ & $\mathrm{C}$ & $\mathrm{H} 24(\mathrm{~L} 10) \mathrm{T}$ \\
\hline $\mathrm{H} 40 / 1$ & $\mathrm{~B}$ & $\mathrm{H} 40$ \\
\hline $\mathrm{H} 85 / 1$ & $\mathrm{~B}$ & H85 \\
\hline \multicolumn{3}{|c|}{$\begin{array}{l}\text { * after Frank \& Moebus (1987) and unpublished data (H24/1) } \\
\text { strain used in first expt. only } \\
\text { H71 exclusively used since } 1989 \\
\text { Hon-lysogenic derivative of } \mathrm{H} 24\end{array}$} \\
\hline
\end{tabular}

about $10^{5} \mathrm{PFU} \mathrm{ml} \mathrm{m}^{-1}$ was attained for each strain employed. Any of the phage strains used could be distinguished from the others by its specific host. As indicated in Table 1 under "Bradley group", the phages are also morphologically different. All test strains listed are virulent ones except H17/1 which, with low efficiency, is able to establish either the carrier state or lysogeny in its host $\mathrm{H} 17$.

Incubations: Generally, seawater samples of $150 \mathrm{ml}$ (in Erlenmeyer flasks of $300 \mathrm{ml}$ capacity), inoculated with the phage mixture, were incubated as still cultures at $20^{\circ} \mathrm{C}$ in a stirred water bath holding 7 flasks. This was placed $50 \mathrm{~cm}$ from a window facing NE which remained unshaded in late winter, but was shaded by a light rolled blind in summer. Initially, two samples each of differently treated seawater were incubated, one of them wrapped in aluminum foil. Later on, only darkened samples were employed to exclude the influences of the uncontrollable light conditions and that of an additionally used water bath of different design.

Double-layer plates (Adams, 1959) with bottom layers of $10 \mathrm{ml}$ SWA were used for $\mathrm{PFU}$ titrations and, in the case of test phage, incubated at $25^{\circ} \mathrm{C}$. All the other plates were incubated at $20^{\circ} \mathrm{C}$. Bacteria (CFU) were grown on SWA $(20 \mathrm{ml} /$ plate) with the plates placed in plastic bags during 7 to 8 days of incubation. Counting of CFU was done under 10-fold magnification with a dissecting microscope. The "Results" will distinguish between $\mathrm{CFU}, \mathrm{CFU}(\mathrm{s})$, and $\mathrm{CFU}(1)$, the latter representing bacterial strains which during 7 days of incubation at $20^{\circ} \mathrm{C}$ produce colonies of $=>2 \mathrm{~mm}$ in diameter. Accordingly, 
CFU(s) represent bacteria producing colonies of less than $2 \mathrm{~mm}$ in diameter under the same experimental conditions. $\mathrm{CFU}=\mathrm{CFU}(\mathrm{l})+\mathrm{CFU}(\mathrm{s})$.

Tests of marine bacteria: Due to previously found results and to the aim of the respective experiment, the tests varied in kind and design. Basically, spot tests were performed by means of 20-point inoculators to transfer bacterial or phage suspensions on to sSWA overlayers seeded with the bacteria to be investigated. SWB was used with bacteria giving rise to colonies that were either difficult to remove from the agar, or to suspend in the medium, or that were of less than about $3 \mathrm{~mm}$ in diameter after 7 days of incubation. All other bacteria were grown in SWB/5. The media were used in $3 \mathrm{ml}$ aliquots and incubated in culture rollers at $1 \mathrm{rpm}$. Except for colony size, selection among CFU was avoided in every possible way.

The most common design of spot tests as described above was used in tests for lysogeny, for production of bacteriocins and inhibitory compounds, for unknown phages, and (initially) for sensitivity to test phage. To enable the screening of more bacterial isolates for sensitivity to well-defined phage suspensions, a different double-spot test was employed later on which shall be described in greater detail.

Suspensions of bacteria to be tested were inoculated by means of 20-point inoculators on 2 to 4 parallel SWA plates. When the fluid was sucked up, the plates were inoculated a second time: One with $\mathrm{SM}$ (control) and the remaining either with a suspension containing only one test phage or with mixtures each containing 3 of the phage strains employed in the respective experiment. The concentration of each phage strain, whether used singly or in mixture, was about $10^{7} \mathrm{PFU} \mathrm{ml} \mathrm{m}^{-1}$. The plates were controlled after 1 day and finally read after 2 days of incubation by carefully comparing the spots, grown on all parallel plates, of each bacterial isolate for differences in appearance. If only the slightest difference between the control spot and the corresponding spots on any "phage plate" was observed, the respective isolate was included in the confirmatory test. This was done by streaking a bacterial suspension, prepared with material isolated from the "control" spot, across streaks of the phage strains in question. To determine the type of reaction of bacteria to phage (lysis or inhibition), isolates found to be sensitive to one or more phage strains were finally spot-tested (on double-layer plates poured with SWB/5 cultures) with serially diluted lysate of the respective phages. The latter test proved to be very important with bacteria sensitive to phage H7/2.

Cell-free preparations (CFP) were prepared from various sources to be described under "Results" by centrifuging $10 \mathrm{ml}$ aliquots, followed by filtration through $0.15 \mu \mathrm{m}$ filters (Sartorius), previously washed with beef extract solution.

To test for the production of virucidal substances, 0.8 or $1.0 \mathrm{ml}$ of the cultures of 4 to 6 bacterial isolates were mixed, centrifuged at low speed, and the supernatants filtered through $0.2 \mu \mathrm{m}$ Nucleopore filters. The filtrates were inoculated with about $10^{7} \mathrm{PFU} \mathrm{ml}^{-1}$ of phage $\mathrm{H} 7 / 2$ plus about $4 \times 10^{6} \mathrm{PFU} \mathrm{m}{ }^{-1}$ of strain $\mathrm{H} 17 / 1$ and checked for surviving PFU after $1,2,3,5$, and 9 days. These two phage strains were used because of their especially high inactivation rates in RSW.

Survival rates day ${ }^{-1}$ were calculated according to the formula $k=\left[\ln \left(C_{t} / C_{0}\right)\right] / t$, where $C$ is the PFU concentration at zero time $\left(C_{0}\right)$ and after $t$ days $\left(C_{t}\right)$, respectively.

Further information on methods will be presented under "Results". 
Table 2. Percentage of survival of 10 strains of test phages under various conditions, with information regarding survival rate: $r_{i}=$ rate increased continuously, $r_{c}=$ constant rate throughout, $r_{d}=$ rate for some time constant, then decreasing, $r_{v}=$ rate varying (decreasing - increasing - decreasing), possibly due to contamination of FSW sample, $0=$ no inactivation. Seawater of February 24, 1988

\begin{tabular}{|c|c|c|c|c|c|c|c|c|c|c|c|}
\hline \multirow{2}{*}{$\begin{array}{c}\text { Test } \\
\text { in }\end{array}$} & \multirow{2}{*}{$\begin{array}{l}\text { Days of } \\
\text { incub. }\end{array}$} & \multicolumn{10}{|c|}{ Bacteriophage strain } \\
\hline & & $\mathrm{H} 17 / 1$ & $\mathrm{H} 7 / 2$ & $\mathrm{H} 6 / 1$ & $\mathrm{H} 24 / 1$ & $\mathrm{H} 2 / 1$ & $\mathrm{H} 3 / 1$ & $\mathrm{H} 4 / 4$ & $\mathrm{H} 11 / 1$ & $\mathrm{H} 40 / 1$ & $\mathrm{H} 85 / 1$ \\
\hline RSW & 27 & 0.6 & 2.4 & 40.1 & 62.6 & 31.5 & 22.6 & 10.9 & 50.8 & 40.5 & 12.7 \\
\hline $\begin{array}{l}5^{\circ} \mathrm{C} \\
\text { dark }\end{array}$ & & $\mathrm{r}_{\mathbf{i}}$ & $\mathrm{r}_{\mathrm{i}}$ & $\mathrm{I}_{\mathrm{C}}$ & $\mathbf{r}_{d}$ & $\mathrm{r}_{\mathrm{c}}$ & $\mathrm{r}_{\mathrm{i}}$ & $\mathrm{r}_{\mathbf{i}}$ & $r_{c}$ & $\mathbf{r}_{\mathbf{i}}$ & $\mathbf{r}_{\mathbf{i}}$ \\
\hline FSW & 27 & 10.4 & 25.6 & 96.8 & 106.3 & 81.4 & 104.2 & 104.9 & 108.7 & 104.6 & 96.9 \\
\hline $\begin{array}{l}5^{\circ} \mathrm{C} \\
\text { dark }\end{array}$ & & $\mathbf{I}_{\mathrm{i}}$ & $\mathbf{r}_{\mathrm{c}}$ & 0 & 0 & $I_{c}$ & 0 & 0 & 0 & 0 & 0 \\
\hline RSW & 12 & $<0.005$ & 1.7 & & & & & & & & \\
\hline $20^{\circ} \mathrm{C}$ & 19 & & & 1.4 & 0.8 & 0.9 & 1.5 & 0.6 & 1.7 & 1.6 & 0.5 \\
\hline light & & $\mathbf{I}_{\mathbf{i}}$ & $\mathbf{r}_{\mathbf{i}}$ & $\mathbf{r}_{\mathrm{i}}$ & $\mathrm{r}_{\mathrm{i}}$ & $\mathbf{r}_{\mathbf{i}}$ & $\mathbf{I}_{\mathbf{i}}$ & $\mathrm{r}_{\mathrm{i}}$ & $\mathbf{r}_{\mathbf{i}}$ & $\mathbf{r}_{\mathbf{i}}$ & $\mathrm{r}_{\mathrm{i}}$ \\
\hline RSW & 12 & $<0.005$ & 3.8 & & & & & & & & \\
\hline $20^{\circ} \mathrm{C}$ & 19 & & 0.3 & 5.1 & 6.3 & 1.4 & 3.1 & 1.9 & 3.5 & 5.4 & 1.3 \\
\hline \multirow[t]{2}{*}{ dark } & 27 & & 0.02 & 3.2 & 3.7 & 0.2 & 0.6 & 0.3 & 0.6 & 1.3 & 0.2 \\
\hline & & $\mathrm{r}_{\mathrm{i}}$ & $r_{c}$ & $\mathbf{r}_{\mathrm{d}}$ & $I_{d}$ & $\mathrm{r}_{\mathrm{c}}$ & $\mathbf{r}_{\mathrm{c}}$ & $I_{C}$ & $r_{c}$ & $\mathrm{r}_{\mathrm{c}}$ & $\mathbf{r}_{\mathrm{c}}$ \\
\hline FSW & 12 & 0.2 & & & & & & & & & \\
\hline $20^{\circ} \mathrm{C}$ & 27 & & 2.0 & 89.1 & 16.8 & 48.1 & 88.3 & 45.8 & 89.1 & 94.3 & 58.4 \\
\hline light & & $\mathrm{I}_{\mathrm{i}}$ & $I_{v}$ & $I_{c}$ & $I_{C}$ & $r_{c}$ & $\mathrm{r}_{\mathrm{c}}$ & $\mathrm{r}_{\mathbf{c}}$ & $\mathbf{I}_{\mathrm{C}}$ & 0 & $\mathbf{r}_{\mathrm{c}}$ \\
\hline FSW & 19 & 0.05 & & & & & & & & & \\
\hline $20^{\circ} \mathrm{C}$ & 27 & & 9.7 & 79.5 & 85.6 & 50.6 & 67.8 & 97.3 & 68.1 & 102.3 & 77.6 \\
\hline dark & & $r_{i}$ & $r_{v}$ & $r_{c}$ & $\mathbf{r}_{\mathrm{d}}$ & $\mathbf{r}_{\mathrm{c}}$ & $I_{c}$ & , $\quad r_{c}$ & $\mathrm{r}_{\mathrm{c}}$ & 0 & $r_{c}$ \\
\hline
\end{tabular}

\section{RESULTS}

Due to the available information, attention was paid to naturally occurring bacterial populations, the alterations of which were followed by repeated titrations of colonyforming units (CFU) during the course of each experiment, and by special tests of bacterial isolates in a number of experiments.

The influence of temperature was considered only during the first experiment, started on February 24, 1988. A mixture of 10 phage strains (Table 1) was used. Results of the experiment are compiled in Table 2. As was to be expected, inactivation of phage generally was much more rapid at $20^{\circ} \mathrm{C}$ than at $5^{\circ} \mathrm{C}$. Except for phage strain $\mathrm{H} 17 / 1$, which under any of the conditions tested was inactivated at ever increasing rates during the experiment, inactivation curves such as shown in Figure 1 were obtained. As can be seen in Table 2, inactivation of most phage strains occurred in FSW, if at all, at a constant rate, irrespective of temperature and light condition. In RSW the latter had a marked influence on the inactivation rate at $20^{\circ} \mathrm{C}$ which, in the illuminated sample, for all test phages increased gradually from the beginning to the end of the experiment. In sharp contrast, the rate of inactivation in the darkened sample remained constant or even decreased after some time, with the already mentioned exception of strain H17/1. Besides these marked differences it must be pointed out that, for the first 12 to 19 days of 


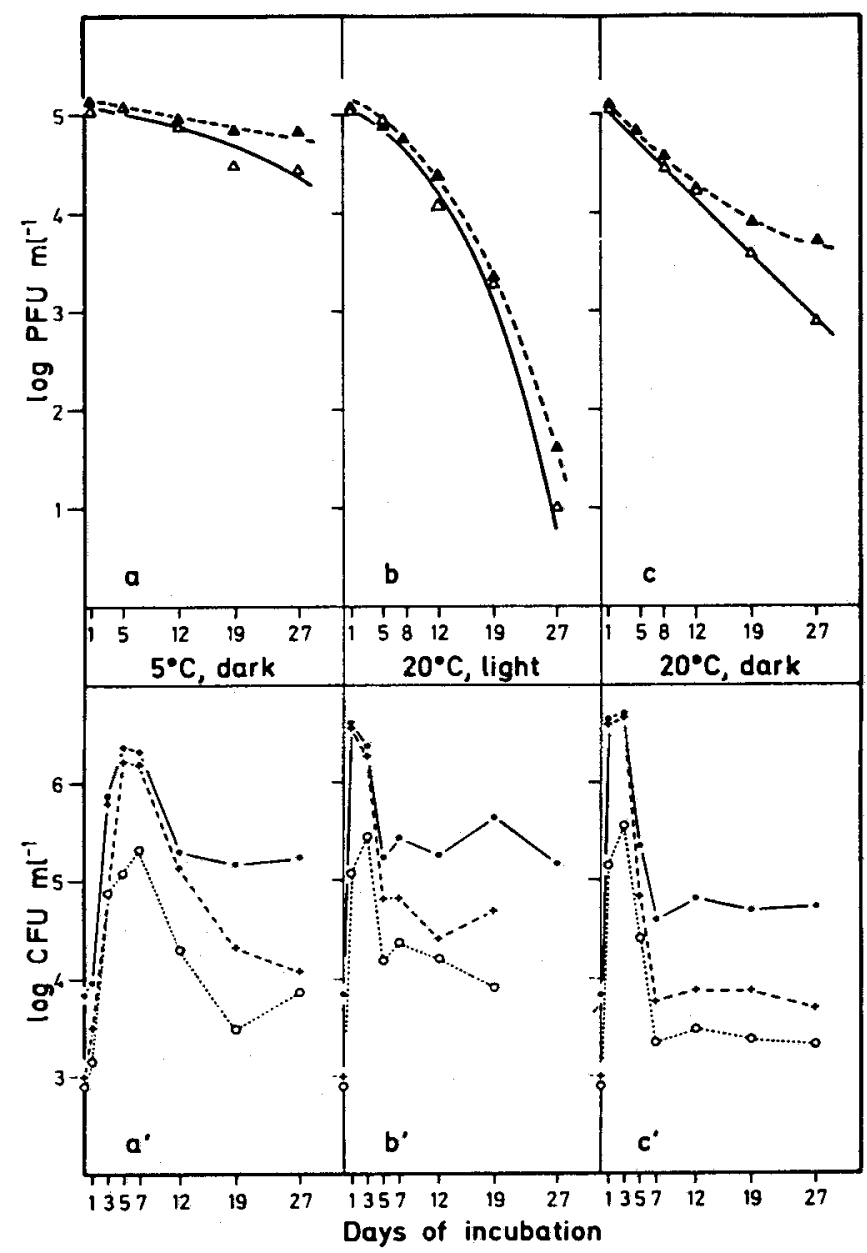

Fig. 1. Inactivation in raw seawater of test phage $H 3 / 1(\Delta)$ and $H 6 / 1(\Delta)$, above, and development of the indigenous bacterial population, below, under the conditions indicated. Seawater sampled on February 24, 1988. $\bullet$ : sum of colony-forming units (CFU); +---+: bacteria forming colonies of $=>2 \mathrm{~mm}$ in diameter under standard conditions; $0 \cdots 0$ : CFU forming coloured colonies

incubation at $20^{\circ} \mathrm{C}, 6$ of the 10 phage strains underwent distinctly more rapid inactivation in the dark than in the light.

Strain H17/1 was known in advance to be sensitive to temperature as well as to unknown factors causing destruction of the virions' complex structure (Frank \& Moebus, 1987) and relatively rapid loss of infectivity even in phage stocks. These traits led to its exclusion from further experiments.

Strain $\mathrm{H} 7 / 2$, the inactivation of which under any of the test conditions was the second most pronounced, was not known before to be conspicuously sensitive to temperatures up to $25^{\circ} \mathrm{C}$. Since, during most of the following experiments, this strain was more rapidly inactivated than any of the other test phages used, temperature may indeed be a major 
factor influencing the survival of $\mathrm{H} 7 / 2$ virions. However, as already observed in this first experiment, bacteria sensitive to $\mathrm{H} 7 / 2$ are probably equally or even more important.

Out of 60 bacterial isolates, derived from plates inoculated with the freshly collected RSW, one isolate each was found to react to $H 7 / 2$ by lysis and inhibition, respectively, but none was sensitive to any of the other 9 test phages. The portion of the $\mathrm{H} 7 / 2$-sensitive bacterial types increased 5- to 10 -fold during the first day of incubation at $20^{\circ} \mathrm{C}$ in illuminated RSW. The importance of such bacteria was indicated by the otherwise negative results of the test for virucidal substances produced by the 60 isolates during growth in SWB/5. Two of 9 samples, being the only ones in which appreciable loss of H7/2 was observed, became turbid after 9 days of incubation. Unfortunately, one sample was lost by accident so that the bacteria causing its turbidity remained unknown (some observations indicate the involvement of a bacterial isolate which was lysed by H7/2). In the other sample, however, the turbidity was found to be caused by bacteria reacting to $\mathrm{H} 7 / 2$ by inhibition. At least in this sample, adsorption of phage to cells was probably the main, or only, reason for the loss of PFU.

The test for lysogeny of 96 bacterial isolates, including the 60 aforementioned ones, also failed to produce positive results. After incubation, many spots of bacterial growth were surrounded by more or less clear zones of varying diameter. However, as revealed by confirmatory tests, none of these zones was caused by phage.

The findings of this first experiment initiated some changes in the set-up of the following, started on June 29 and July 18, 1988. Essentially, the two summer experiments of 1988 were performed in the same way, i.e. with the double-spot test, as described under "Material and Methods" and used throughout. With the exception of minor deviations, this holds true also for the experiments of 1989 and 1990.

Besides RSW and FSW, samples of RSW diluted with 4,parts of FSW (= RSW/5) were employed in summer 1988. In the second of these experiments, a sample of $10 \mu$-RSW produced by careful inverse filtration of RSW through $10 \mu \mathrm{m}$-mesh gauze, was also included. The latter sample was used illuminated only. The results of these experiments are presented in Figures 2 and 3. With the exception of the findings for phage $\mathrm{H} 7 / 2$ in FSW, the curves represent arithmetic mean values of percent survival calculated from the results obtained with the 8 or 9 test phages, respectively. Maximum and minimum percentage of survival observed on the sampling day with any of the test phages are represented by various symbols.

At first glance, the similarities between the results of both experiments are more conspicuous than the differences. Firstly, irrespective of light condition, phage inactivation in RSW and RSW/5 generally occurred in three consecutive phases, differing in the rates of PFU loss. In this respect, the results differ greatly from those obtained with RSW collected in late winter. Secondly, the rate of phage inactivation was highest at times of pronounced decreases in CFU and CFU(l) concentration. Thirdly, with the exception of phage $\mathrm{H} 7 / 2$, inactivation in FSW was always slow, with some test phage even negligible.

Besides these similarities, there are also profound differences. While in the first experiment with "summer water" the most pronounced inactivation was almost exclusively observed with phage $\mathrm{H} 7 / 2$ (Figure 2, circles), this position was often occupied by phage H4/4 during the second experiment (Figure 3, asterisks). In regard to the test phages that exhibited the slowest inactivation, the differences between both experiments were less pronounced. Finally, it must be pointed out that differences were found 


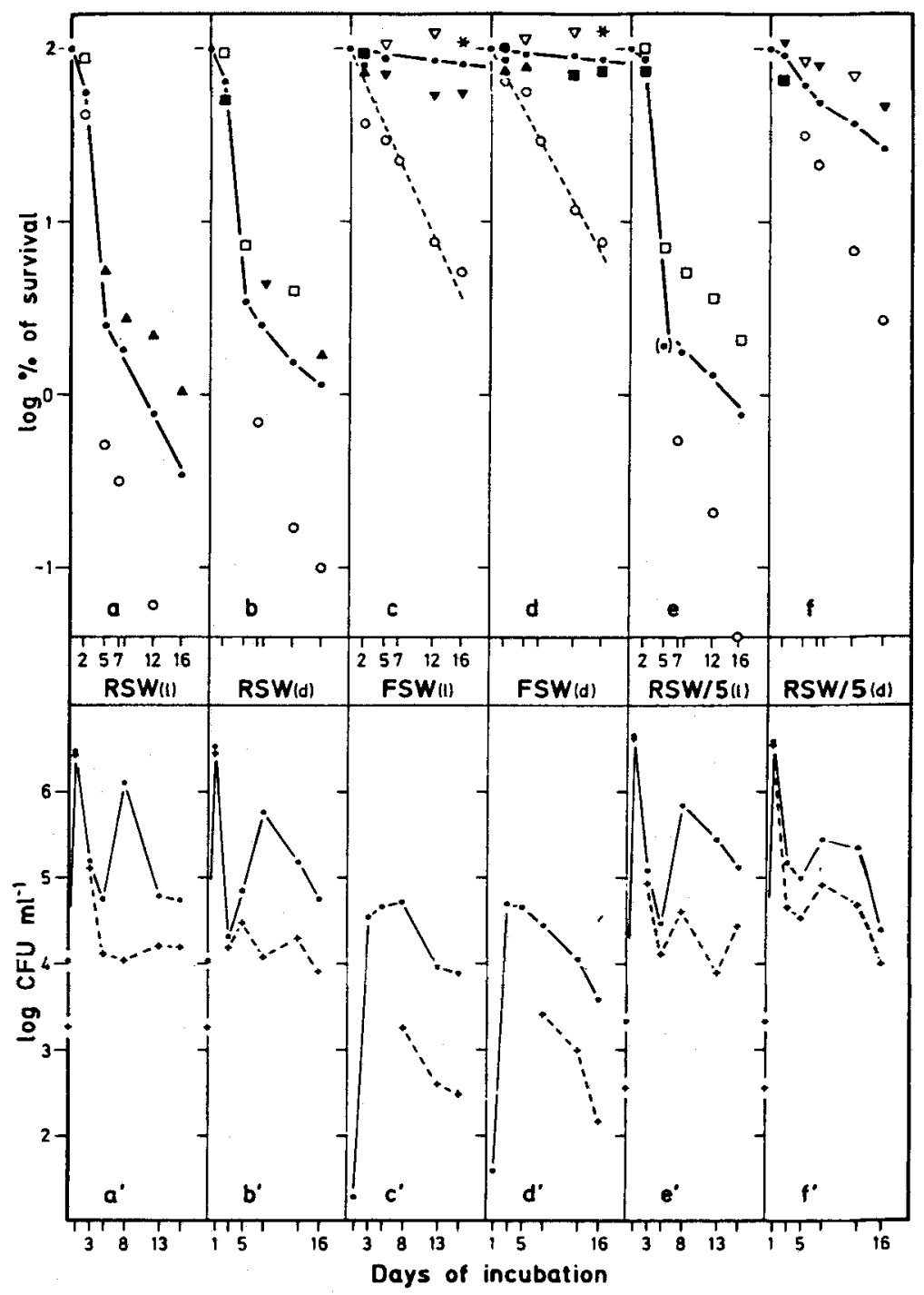

Fig. 2. Inactivation of test phages at $20^{\circ} \mathrm{C}$ in raw seawater (RSW), membrane filtered seawater (FSW), and in RSW diluted with 4 parts of FSW (RSW/5), above, in illuminated (1) and darkened (d) samples, and development of bacterial populations, below. Seawater of June 27, 1988. The inactivation curves $(-\bullet)$ are based on arithmetic mean values of $\log \%$ of survival observed for 9 strains (RSW, RSW/5) and of 8 strains (FSW) of test phage, respectively. Other symbols represent log \% of survival actually observed with the respective test phage (except for $\mathrm{H} 7 / 2$, only maxima and minima on respective day are shown): $\mathbf{m}_{\mathrm{H}} \mathrm{H} 2 / 1 ; \star: \mathrm{H} 4 / 4 ; \boldsymbol{A}: \mathrm{H} 6 / 1 ; 0: \mathrm{H} 7 / 2 ; \nabla: \mathrm{H} 11 / 1 ; \mathbf{v}: \mathrm{H} 24 / 1 ; 0: \mathrm{H} 40 / 1 ;$ H85/1. Symbols for CFU as in Figure 1 


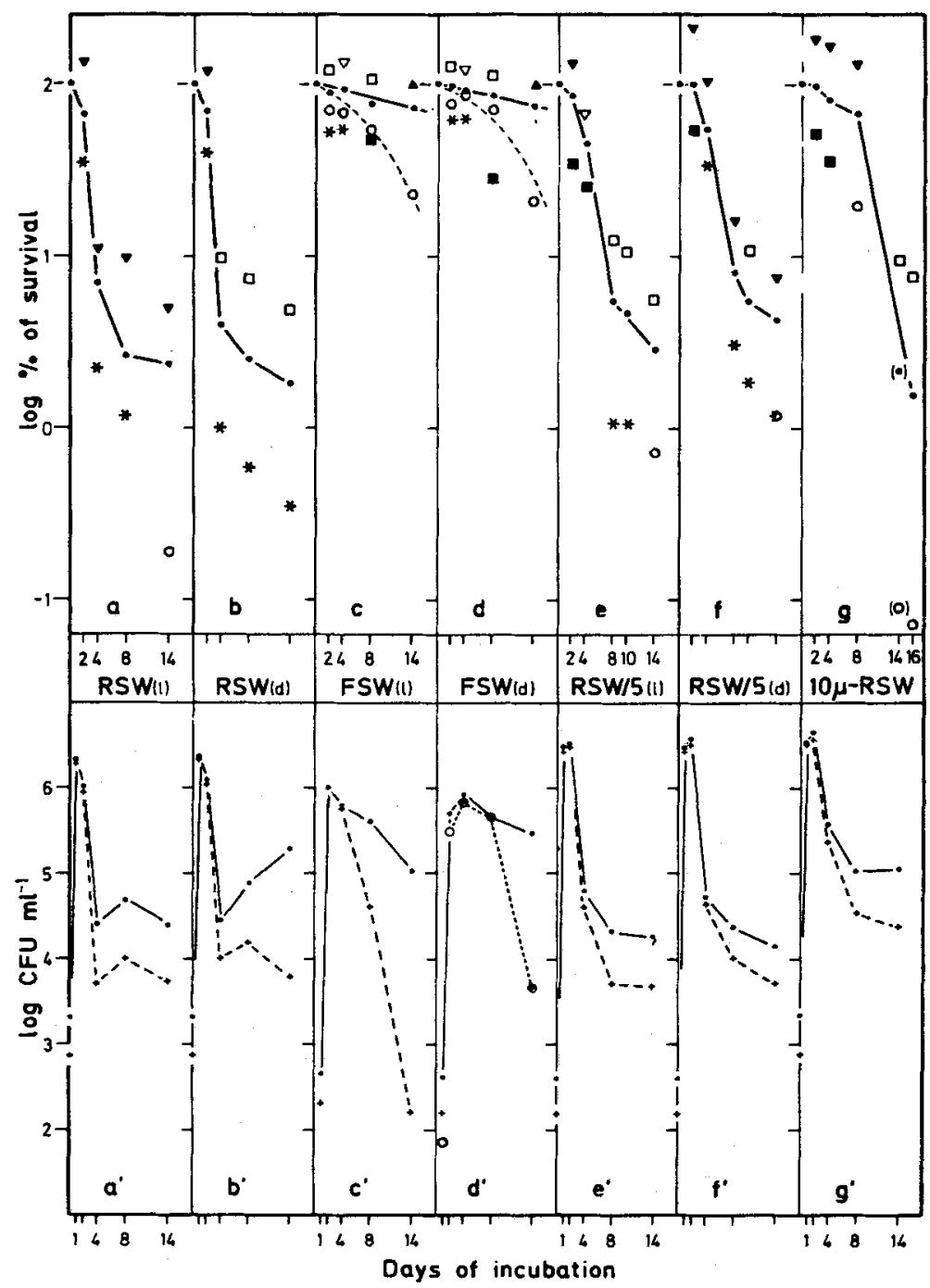

Fig. 3. Inactivation of test phage in RSW, FSW, RSW/5, and RSW inversely filtered through $10 \mu \mathrm{m}$ mesh gauze $(10 \mu-\mathrm{RSW})$ at $20^{\circ} \mathrm{C}$, above, and development of bacterial populations, below, $10 \mu$-RSW under light condition only. Seawater of July 18, 1988. For further information and symbols.see Figs 1 and 2

between the illuminated and darkened samples of RSW/5 in both experiments as well as differences from the findings obtained with RSW.

The first experiment of 1989 was started on March 6 and performed with all test phages listed in Table 1 except with strain H17/1. Its results in no way resemble those obtained in 1988 with "winter water" collected on February 24. Instead, as in "summer water" of 1988, with most test phages a 3-phasic inactivation in illuminated samples of RSW and RSW/5 was observed. As can be deduced from the survival rates compiled in 
Table 3. Survival rates day ${ }^{-1}$ of 9 test phages in RSW, FSW, and RSW/5 of March 6, 1989

\begin{tabular}{|c|c|c|c|c|c|c|c|c|c|c|}
\hline \multirow{2}{*}{$\begin{array}{c}\text { Sample } \\
\text { Test } \\
\text { phage }\end{array}$} & \multicolumn{2}{|c|}{ RSW light } & \multicolumn{2}{|c|}{ RSW dark } & \multicolumn{2}{|c|}{$\begin{array}{c}\text { F.SW light } \\
\text { Incubation (days) }\end{array}$} & \multicolumn{2}{|c|}{ RSW/5 light } & \multicolumn{2}{|c|}{ RSW/5 dark } \\
\hline & $0-9$ & $0-23$ & $0-9$ & $0-23$ & $0-9$ & $0-23$ & $0-10$ & $0-23$ & $0-10$ & $0-23$ \\
\hline $\mathrm{H} \quad 2 / 1$ & 0.83 & 0.85 & 0.88 & 0.81 & 0.95 & 0.94 & 0.92 & 0.90 & 0.95 & 0.88 \\
\hline $\mathrm{H} \quad 3 / 1$ & 0.88 & 0.89 & 0.89 & 0.67 & 1.00 & 1.02 & 0.79 & 0.82 & 0.96 & 0.71 \\
\hline $\mathrm{H} \quad 4 / 4$ & 0.79 & 0.84 & 0.86 & 0.67 & 0.92 & 0.96 & 0.81 & 0.77 & 0.93 & 0.76 \\
\hline $\mathrm{H} \quad 6 / 1$ & 0.87 & 0.89 & 0.88 & 0.86 & 1.00 & 0.99 & 0.88 & 0.86 & 0.96 & 0.85 \\
\hline $\mathrm{H} \quad 7 / 2$ & 0.74 & 0.74 & 0.74 & 0.69 & 0.90 & 0.87 & 0.83 & 0.77 & 0.92 & 0.76 \\
\hline $\mathrm{H} 11 / 1$ & 0.88 & 0.89 & 0.91 & 0.72 & 0.98 & 0.98 & 0.88 & 0.82 & 0.97 & 0.75 \\
\hline H 24/1 & 0.86 & 0.86 & 0.90 & 0.83 & 0.96 & 0.96 & 0.84 & 0.81 & 0.60 & 0.81 \\
\hline $\mathrm{H} 40 / 1$ & 0.93 & 0.92 & 0.94 & 0.74 & 0.99 & 0.99 & 0.90 & 0.84 & 0.99 & 0.78 \\
\hline H $85 / 1$ & 0.84 & 0.87 & 0.86 & 0.69 & 0.91 & 0.99 & 0.85 & 0.80 & 0.97 & 0.71 \\
\hline
\end{tabular}

Table 3, for up to 9 or even 16 days of incubation the survival rates of most test phages in darkened RSW samples equalled those found with illuminated RSW. Then they increased sharply to rates that generally remained constant until the end of the experiment, resulting in much stronger total inactivation in darkened than in illuminated RSW. This is in stark contrast to the results of the experiment started in February 1988.

In RSW/5, fundamentally the same observations were made with one exception: In illuminated RSW/5 the inactivation rate generally increased after only 5 days, but in darkened RSW/5 after 9 days of incubation. Incidentally, almost identical total inactivation in illuminated and darkened RSW/5 (as indicated by corresponding k values for 0-23 days) was observed with 5 test phages.

Figure 4 presents the findings of one of two experiments aimed at estimating the influence of light on phage inactivation and at testing the trustworthiness of results obtained by employing only one sample each of the variously treated seawater. Only RSW, inoculated with the 4 test phages indicated, was used with 3 parallel samples under each light condition. In the other experiment, the same degree of correspondence was found. With RSW subsamples employed under somewhat differing conditions, e.g. in volumes of 500 and $150 \mathrm{ml}$, or with titrations performed each day versus every second day, respectively, a high degree of correspondence also was generally found. This was even the case with a sample prepared from RSW/+ (for explanation see next paragraph) by dilution with FSW to re-establish the original concentration of particulate matter of $\geq 10 \mu \mathrm{m}$ in size.

In each experiment performed since the summer of 1988, it was found that the period of most rapid phage inactivation occurred in seeming synchrony with the rapid loss of CFU taking place after their initial increase. To get some clue of the responsible factor(s), experiments were performed employing samples of unprocessed RSW, of $10 \mu$-RSW, and of RSW/+, the latter being the residue of inverse filtration of RSW to produce $10 \mu-\mathrm{RSW}$, with the concentration of particulate matter of $\geq 10 \mu \mathrm{m}$ in size increased by factors between 10 and 15 .

The results of two experiments of this kind, performed with samples collected on June 26 and August 11, 1989, differed in too many aspects to be presented in detail. Some 


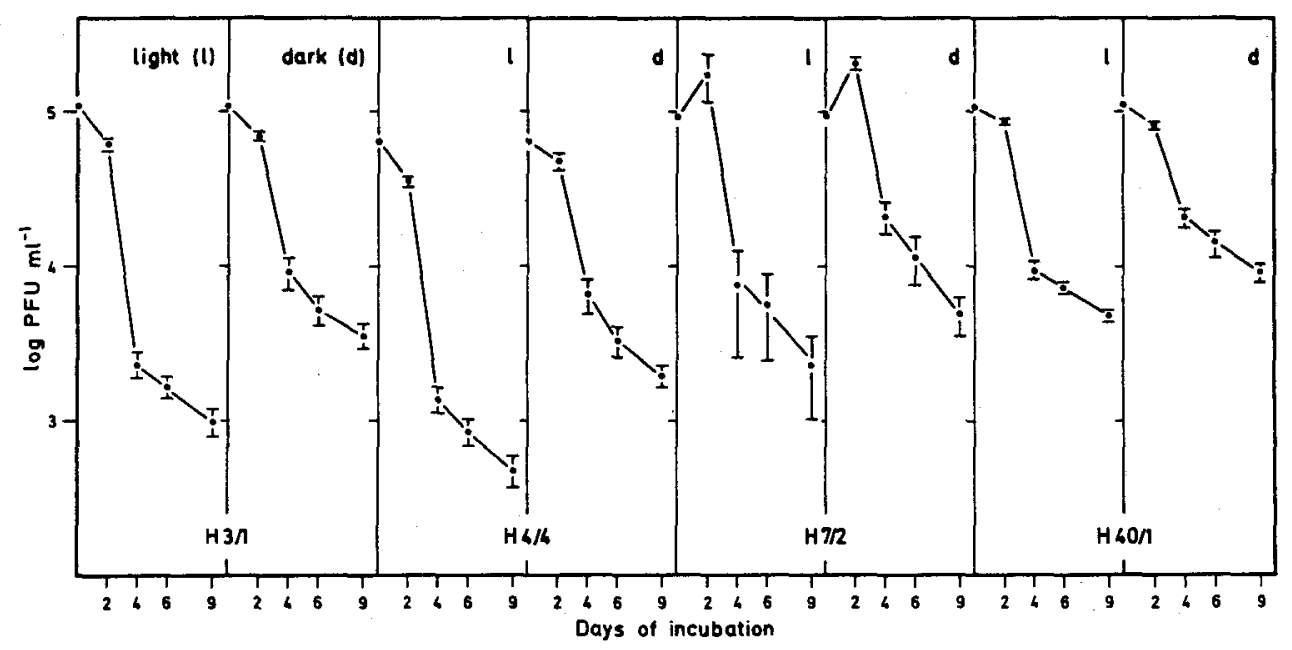

Fig. 4. Inactivation of 4 test phages in raw seawater of July 24,1989 at $20^{\circ} \mathrm{C}$ in 3 parallel samples each under light (l) and dark (d) condition. Bars represent standard error of means

characterizing data obtained with darkened samples (no illuminated samples were used in the second experiment) are compiled in Table 4. The only similarity observed in both (as in many other) experiments concerns phage $\mathrm{H} 7 / 2$ which was the most sensitive, and strain H40/1 which was the least sensitive of 6 and 4 test phages, respectively, under any of the conditions. (This is also true regarding illuminated samples of the first experiment.) The following conspicuous differences were found:

(1) During the first experiment, inactivation in the 3 media was mostly of the 3-phasic type such as depicted in Figure 4, while in the second experiment the 2-phasic type prevailed, with a constant inactivation rate attained after $2(\mathrm{H} 7 / 2)$ or 8 days (other test phages). With RSW/+, however, a completely different course of inactivation was observed during the second experiment with all 4 test phages: negligible change in PFU concentration during the initial 2 days was followed by inactivation lasting for 2 days, which was followed by at least 4 days of slow (H7/2) or no loss in PFU. Only then, after 8 to 11 days of incubation, did phage inactivation resume at rates similar to those observed between 2 and 4 days.

(2) Regarding the development of bacterial populations, the greatest differences between the results of both experiments were found with RSW, and the smallest with RSW/+. During the first experiment, bacterial growth in the 3 different seawater qualities showed the most common pattern of maxima attained after 1 to 2 days which were followed by rapid losses during the next 2 to 3 days. As usual, these losses were more pronounced for CFU(l) than for the entire CFU populations. In contrast, during the second experiment the initial increase and the following reduction in CFU concentration were of about normal extent only in relation to the entire populations. Regarding CFU(l), however, reproduction in RSW/+ was somewhat less than normal, while reduction was of normal extent but needed about twice the usual time; in $10 \mu$-RSW and RSW the CFU(l) maxima were only about and less than $10 \%$ of the 
Table 4. Comparison of $\%$ survival and survival rates day ${ }^{-1}$ of test phage $H 7 / 2$ and H40/1 (above) and of development of CFU ml ${ }^{-1}(\mathrm{~T}$, below), as observed in darkened samples of RSW, 10 $\mu$-RSW, and RSW $/+$. Seawater sampled on June 26 (exp, 1) and August 11, 1989. Duration of experiments was 9 and 17 days, respectively. Numbers in brackets = days of incubation

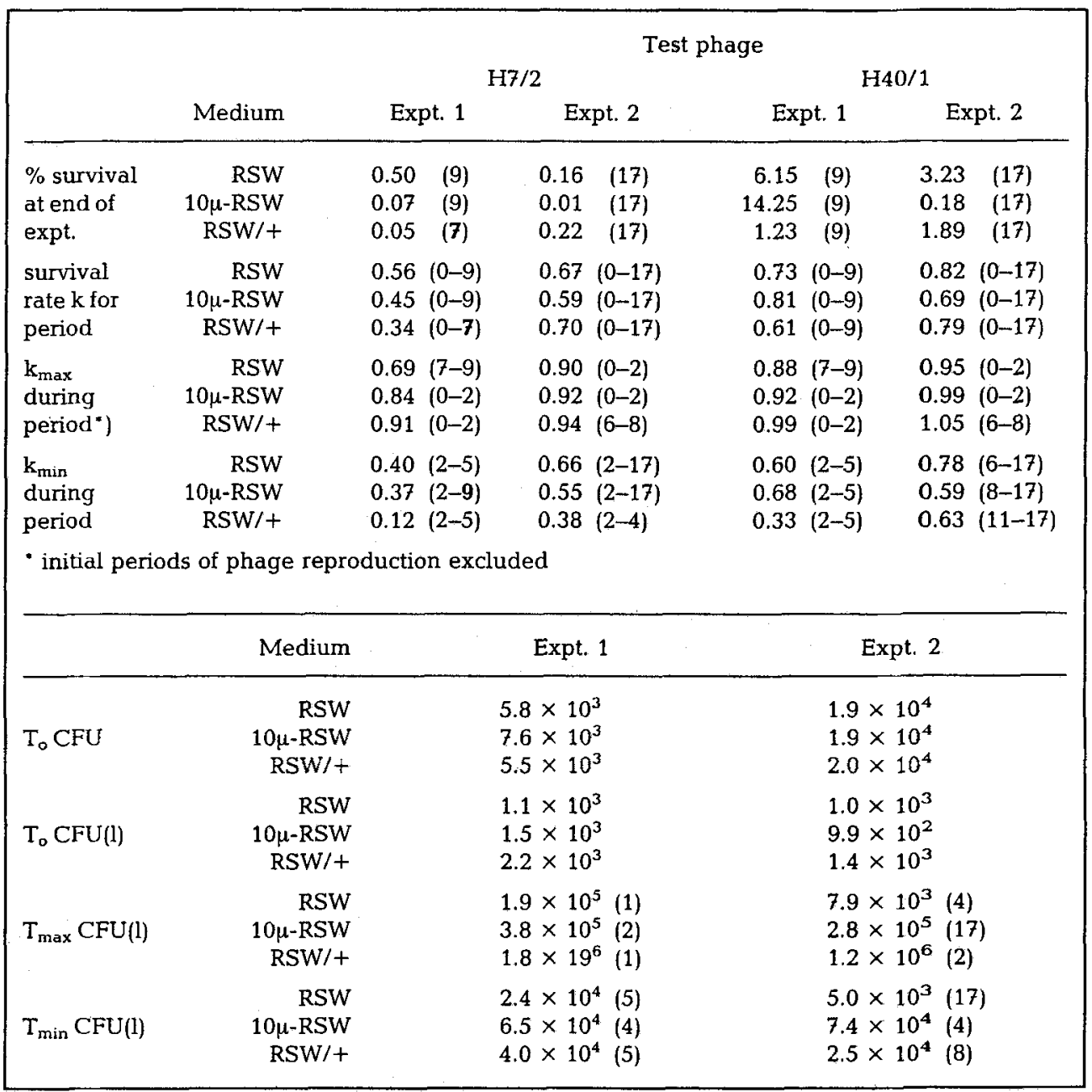

whole population, respectively, and their reduction in $10 \mu$-RSW reached unprecedented $55 \%$ only, while in RSW the CFU(l) did not decrease at all. (In two parallel RSW aliquots of the sample collected on August 11, which were inoculated with only two test phages but sampled daily, the development of bacteria was "normal" except for the maxima of CFU(1): with only $20 \%$ they fell short of the usual 90 to $95 \%$ and were attained 1 day after those of the entire populations.)

The RSW sampled on August 11 was also used to test the influence of pre-incubation on phage inactivation. For this purpose, 3 samples of equal size were prepared and inoculated with 4 test phages at time zero, after 2 , and 4 days of incubation, respectively 
(samples 1 to 3). To compensate for nutrients introduced with the test phages, comparable amounts of peptone and yeast extract were added to samples 2 and 3 at zero time, and to sample 1 after 4 days. The findings are presented in Figure 5, whereby those regarding test phage $\mathrm{H} 4 / 4$ are omitted because of similarity with strain $\mathrm{H} 3 / 1$. The curves shown are certainly debatable, especially in regard to sample 1 (Figure 5a); however, they clearly demonstrate that during pre-incubation considerable changes in virucidal capacity of the seawater took place.

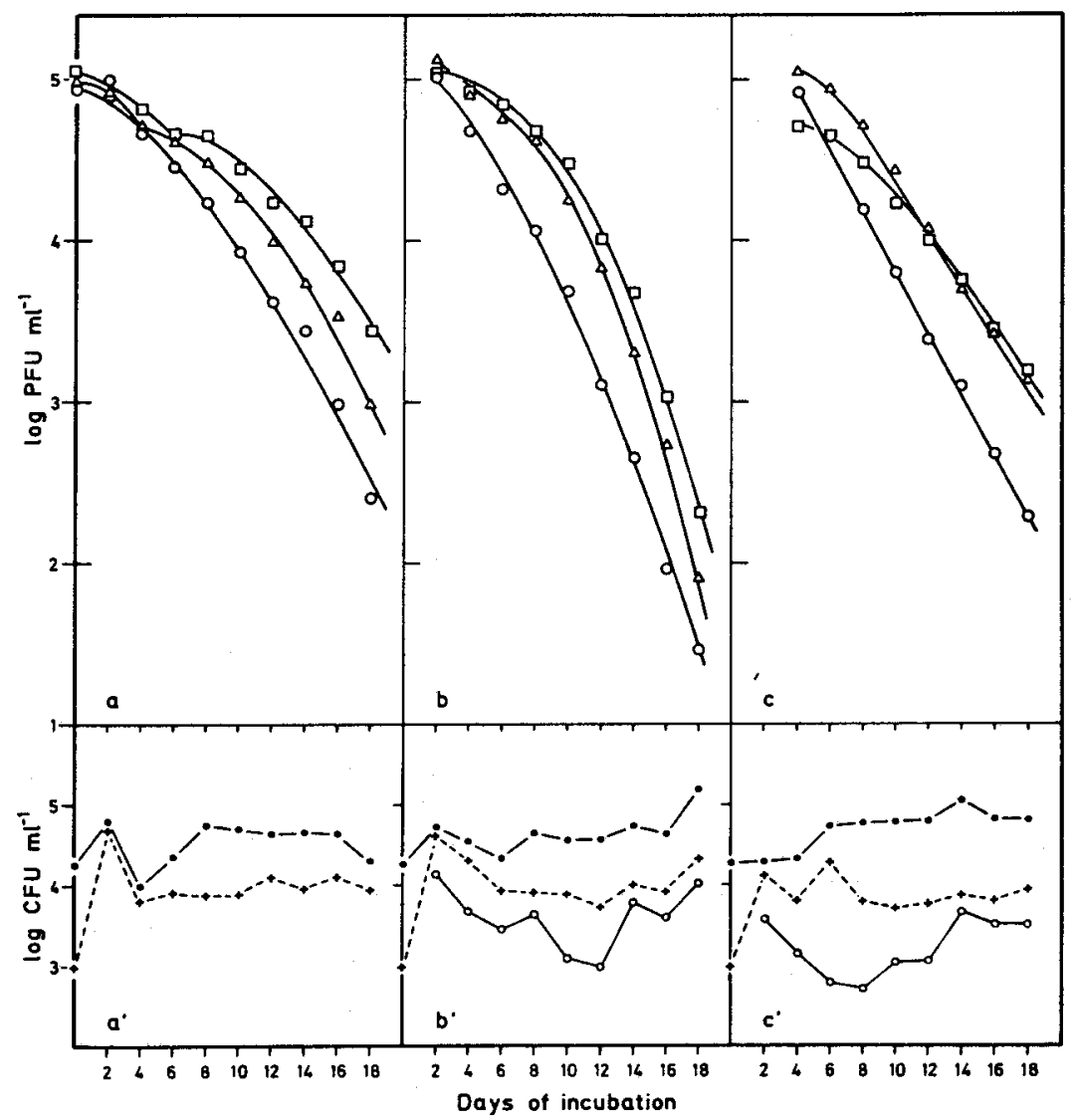

Fig. 5. Inactivation of test phage $\mathrm{H} 3 / 1(\Delta), \mathrm{H} 7 / 2(0)$, and $\mathrm{H} 40 / 1$ (口) in raw seawater of August 11, 1989, above, and development of bacterial populations, below, at $20^{\circ} \mathrm{C}$. Test phage mixture was inoculated at once (a) and after 2 (b) and 4 days (c) of pre-incubation. Peptone and yeast extract, corresponding to amounts introduced along with test phage, were added at zero time (b, c) and after 4 days of incubation (a), respectively. - - Entire CFU population; +---+: CFU forming colonies of $=>2 \mathrm{~mm}$ under standard conditions; 0 : CFU sensitive to test phage $\mathrm{H} 7 / 2$

During the experiments performed with seawater collected on August 11, nearly 2600 bacterial isolates were tested for sensitivity to phage H7/2. Only this phage strain was used because of the rareness of bacteria sensitive to the other test phages employed, as indicated by previous findings. The concentrations of $\mathrm{H} 7 / 2$-sensitive bacteria, as 
calculated from the percentages found among the CFU(l) tested, are shown in Figure 5 (circles in $b^{\prime}, c^{\prime}$ ). Despite considerable concentrations of $\mathrm{H} 7 / 2$-sensitive bacteria during the early phase of incubation, no reproduction of $\mathrm{H} 7 / 2$ was found, which obviously must be attributed to large portions of sensitives reacting to this phage by inhibition. Accordingly, H7/2-PFU were lost, at least in part, by adsorption to such bacteria (which thereby were killed), with the $\mathrm{H} 7 / 2$-sensitives increasing again when the concentration of $\mathrm{H7} / 2$ PFU was reduced to less than $10^{3} \mathrm{ml}^{-1}$.

Quite similar findings were obtained with one of the two daily sampled RSW aliquots referred to above, while the development of $\mathrm{H} 7 / 2$-sensitive bacteria in the second one took an errant course, almost leading to their extinction. In both of these RSW portions, slight phage reproduction occurred between 1 and 2 days of incubation followed by inactivation at constant rate $(\mathrm{k}=0.72$ and 0.73$)$ to final $H 7 / 2$ concentrations of $7.3 \times 10^{2}$ and $5.6 \times 10^{2} \mathrm{PFU} \mathrm{ml}{ }^{-1}$, respectively, after 18 days. (For comparison: The inactivation curve shown for $\mathrm{H} 7 / 2$ in Figure $5 \mathrm{c}$ corresponds to $\mathrm{k}=0.65$, while $\mathrm{k}=0.73$ was calculated for $\mathrm{H} 7 / 2$ inactivation between 2 to 12 days in the sample represented by Figure 5a.)

The results presented so far indicate that bacteria might be involved in the reduction of PFU concentration in at least two different ways: by adsorption of virions without following phage reproduction and by production of virucidal substances. The conception that such substances are possibly released at times of pronounced decreases in CFU concentration, as observed after 2 to 3 days of incubation, is supported by another observation made with the seawater of August 11 (cf. Fig. 6).

From this water the only non-sterile FSW sample of 1989 was produced, which seemingly was contaminated with two types of CFU, one forming colonies of about $1 \mathrm{~mm}$ in diameter, and the other forming much more but smaller ones under standard conditions. On plates inoculated with undiluted FSW after $A$ days of incubation, plaque-like disturbances in an incomplete bacterial lawn were observed. Later on, the larger colony type was completely replaced for some time by the smaller one, but it appeared again, forming then slightly more opaque colonies while the smaller colony type was wiped out. Although attempts to isolate the lytic principle thought to be responsible for these observations remained futile, the findings concerning inactivation of test strain $\mathrm{H} 7 / 2$ (Fig. 6 , above) support the conception of dying bacteria being an important source of virucidal substances: The survival rate, in strict correlation to the phases of bacterial development, decreased from $k=0.99$ (0-2 days) to $k=0.89$ (2-8 days) and to $k=0.75$ (8-17 days), with the lowest rate found in connection with the break-down of the bacterial population.

Several experiments of different design, using ASW(e) as medium and mixtures of arbitrarily selected CFU(l) or known PHS, were unsuccessful in producing support of the aforementioned conception. Also, a bacterial strain forming large greenish-yellow colonies, which suppressed growth of all other CFU(l) (see Fig. $3 \mathrm{~d}$ '), had almost no effect on the survival of phage $\mathrm{H} 7 / 2$.

However, when, in an experiment started on March 19, 1990, a sample of $3 \mu$-RSW was used, prepared by means of Sartorius fibre filters of $3.0 \mu \mathrm{m}$ mean pore size to remove heterotrophic flagellates, the development of the bacterial flora and the inactivation of test phage were considerably influenced by the filtration procedure (Figure $7 a^{2}, a^{\prime}, b, b^{\prime}$ ). This observation initiated the isolation of arbitrarily selected CFU(s) and CFU(l) grown on plates inoculated after 4 and 9 days, respectively, of incubation of the RSW (sic) sample, which were used to prepare mixtures of about equal turbidity before inoculation into 


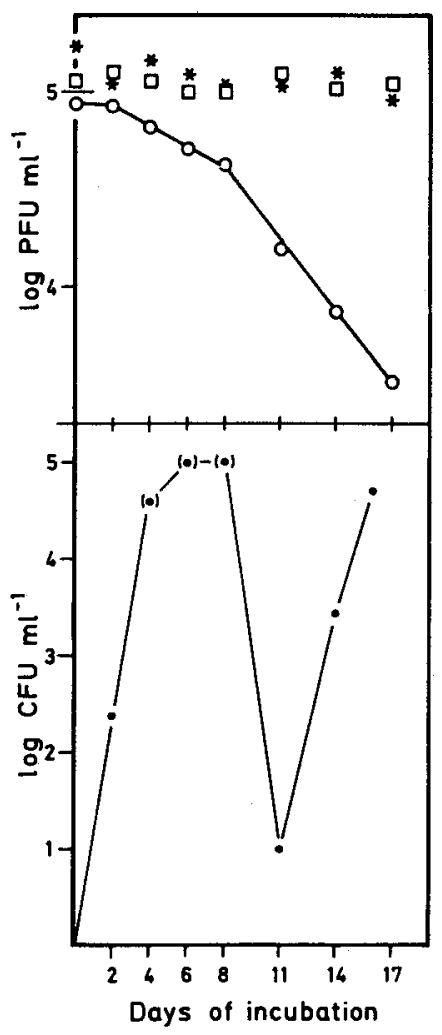

Fig. 6. Survival of test phage $H 4 / 4(\star), H 7 / 2(\circ)$, and $H 40 / 1$ ( $($ ), above, in an unintentionally contaminated sample of membrane-filtered seawater of August 11, 1989, and development of a bacterial population, below, probably comprising no more, or even less, than 3 different types of CFU forming colonies of maximally $1 \mathrm{~mm}$ in diameter under standard conditions. ( $\bullet$ ) indicates estimates of CFU, with possibly underestimated (overestimated) numbers on plates inoculated after 6 (8) days of incubation of sample at $20^{\circ} \mathrm{C}$. For further information see text

ASW(e), enriched with $0.5 \mathrm{ml} \mathrm{SWB} \mathrm{1}^{-1}$. Mixture no. 1 (Figure $7 \mathrm{c}, \mathrm{c}^{\prime}$ ) was made of 39 CFU(l), mixture no. 2 (Figure $7 \mathrm{~d}^{\prime} \mathrm{d}^{\prime}$ ) contained $47 \mathrm{CFU}(\mathrm{s})$, and mixture no. 3 consisted of equal portions of mixtures 1 and 2 . The findings obtained with mixture no. 3 are not shown, since they differed from those shown in Figure $7 c^{\prime} c^{\prime}$ only in regard to phage $\mathrm{Hz} / 2$ inactivation, which at reduced rates followed the sigmoidal pattern observed with mixture 1.

Regarding phage inactivation, the most interesting findings concern strain $H 7 / 2$. In RSW and ASW(e)+CFU(l), on the one hand, and in $3 \mu-$ RSW and ASW(e)+CFU(s), on the other hand, besides the differences in final loss of PFU, the course of inactivation was similar within each group of samples but very different between both the groups. The survival rates in the samples of the first group differed by values of $k=0.55$ (days 7 to 14) and $\mathrm{k}=0.67$ (days 5 to 11), respectively. Almost perfect correspondence, however, was observed with the samples of the second group: $\mathrm{k}=0.96$ (days 9 to 21 ) and $\mathrm{k}=0.94$ (days 5 to 14$)$, respectively. 


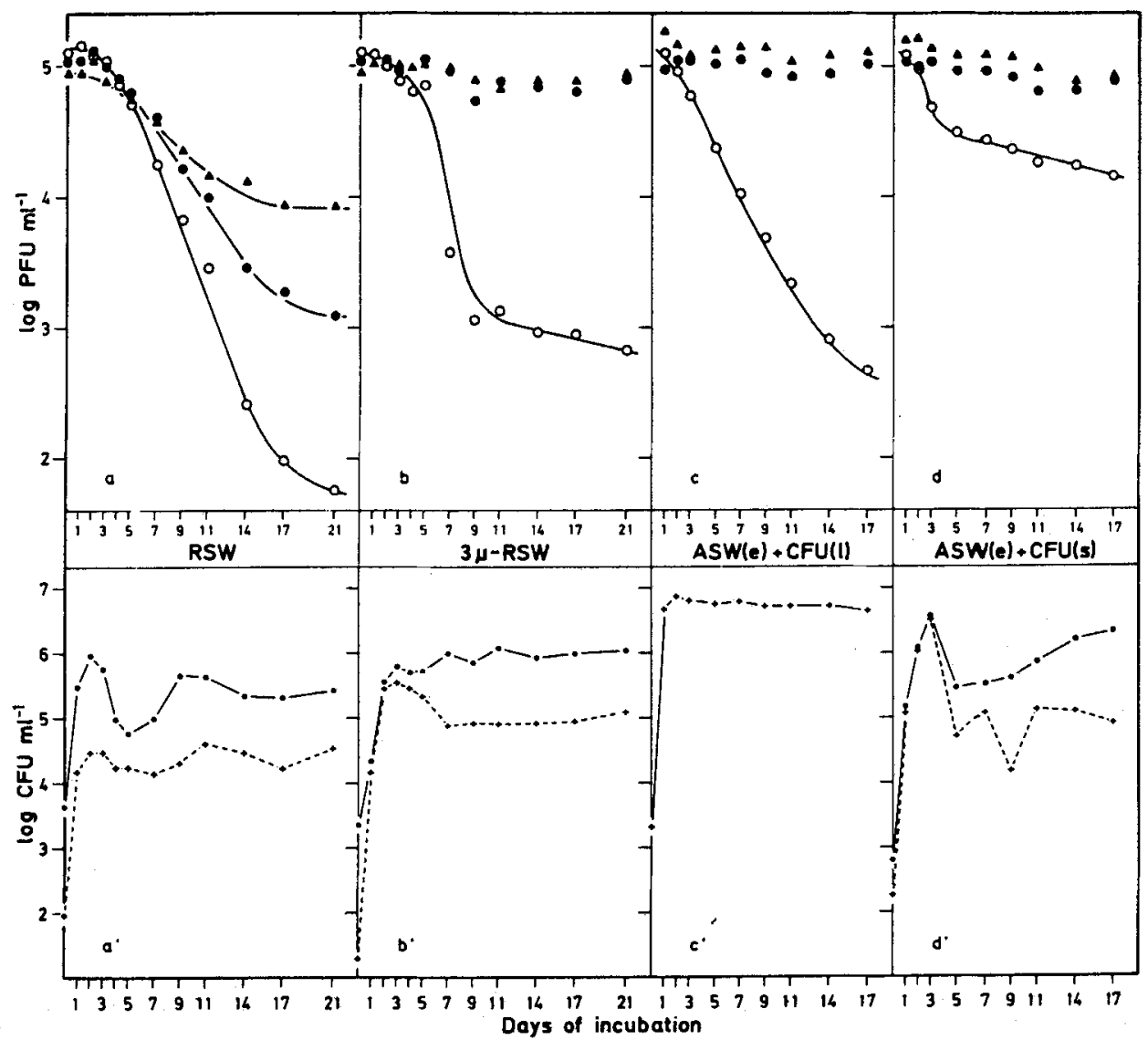

Fig. 7. Inactivation of test phage $\mathrm{H6} / 1$ ( 4$), \mathrm{H} 7 / 2$ (), and $\mathrm{H} 85 / 1(\bullet)$, above, at $20^{\circ} \mathrm{C}$ in RSW, in RSW filtered through membrane of $3 \mu \mathrm{m}$ mean pore size $(3 \mu-\mathrm{RSW})$, and in nutrient-enriched autoclaved (aged) seawater, ASW(e), inoculated with mixtures of CFU forming large (l) or predominantly small (s) colonies, respectively, and development of bacterial populations, below. Seawater of March 19, 1990. Symbols for bacteria as in other Figures, except in Fig. $7 c^{\prime}$ where CFU(l) represent the entire population

As found in other experiments using selected CFU(1), no decrease in CFU concentration occurred (the same applies to the sample inoculated with mixture no. 3). In contrast, in the sample inoculated with the CFU(s) mixture, which unintentionally contained few types of CFU(1), the development of the bacterial population showed the pattern usually found with RSW samples: the initial increase in CFU concentration was followed by a reduction to about $10 \%$ of the maximum within a few days, the reduction being more pronounced for $\mathrm{CFU}(1)$ than for the bacterial community as a whole. Although this pattern developed more clearly in ASW(e)+CFU(s) than in $3 \mu$-RSW, the loss of H7/2PFU in the latter medium was much stronger than in the first mentioned one. Notwithstanding, in relation to the mechanism of phage inactivation, the similarity between the 
shape of the inactivation curves found with these samples is regarded as being more important than the differences in extent of PFU losses.

The two groups of samples differed very much in regard to the preponderance of CFU(s) in $3 \mu$-RSW and, of course, in ASW(e)+CFU(s) which is less distinctly expressed in the graphs than observed by the experimentator. Minutiae taken during evaluation of plates indicate that CFU(l) present in the RSW sample (Figure $7 \mathrm{a}, \mathrm{a}^{\prime}$ ) exerted strong inhibition of CFU(s), which was hardly noticed with regard to $3 \mu$-RSW (the only reference to inhibition was made for the plates inoculated after 4 days of incubation but marked with ?). Moreover, the mean size of colonies developed by CFU(s) from $3 \mu$-RSW was distinctly smaller than that of CFU(s) colonies grown from RSW. Most probably this was due to the greatly reduced, if present at all, inhibition by CFU(1) in plates inoculated with $3 \mu$-RSW which allowed for the development of a much higher portion of tiny colonies (about $0.1 \mathrm{~mm}$ in diameter, the smallest size taken into account). In ASW(e)+ CFU(s) the preponderance of CFU(s) did not mainly depend on their concentration but on the number of different CFU(s), as compared to CFU(l), the latter being represented by 3 different types at the most.

From that time on, the conception of phage inactivation was mainly based on structural damage caused by substances, especially enzymes, released by CFU in connection with their rapid decrease in concentration after more than 2 to 3 days of incubation. The efficacy in regard to inactivation of different phage strains assumedly would depend on the diversity of compounds released which, on its part, should depend on the diversity of bacterial strains involved.

The last mentioned results fit into this concept insofar as inactivation of phage other than $H 7 / 2$ occurred only in RSW having the most diverse bacterial population, and inactivation of $\mathrm{H} 7 / 2$ can be explained by predominant adsarption to sensitive cells which were present in low numbers in the freshly sampled RSW but multiplied rapidly during incubation. Therefore, the chance of isolating such sensitives for production of the CFU(l) mixture was high. The slower and much smaller loss of H7/2-PFU in $3 \mu-R S W$ and $A S W(e)+C F U(s)$, respectively, can be explained in the same way with reduced numbers of sensitive cells at the beginning of incubation taken into account.

Although most observations made during this investigation fit quite well into the concept used to interpret phage inactivation, there was still no plausible explanation for the rapid loss of CFU generally observed immediately after an initial phase of rapid multiplication. As indicated by the results of experiments with mixed populations consisting of relatively few different bacterial strains, lack of nutrients and/or oxygen or intoxication by metabolic products are hardly reasons to be taken seriously. However, bacteriophages and bacteriocins could be prime factors, the latter being shown to provide for competitive dominance of a marine bacterium in mixed populations (Hoyt \& Sizemore, 1982). The involvement of bacteriocins in the die-away of sensitive cells should be relatively simple to prove; that of bacteriophages, however, would be a major problem.

Regarding bacteriophages, it was necessary to test high numbers of bacterial isolates derived from each of successively collected samples of seawater for their sensitivity to phage present in the respective as well as in previous samples, and to simultaneously build up a collection of phage-host systems (PHS) of the greatest possible diversity. Only then might there be a chance to elucidate the possible role of phages in reducing the concentration of CFU in question. Experiments performed in 1990 were dedicated in part 
to the build-up of a collection of PHS. As to the other part, the aim of the experiments was to check for the involvement of bacteriocins, and to gather preliminary experience on the involvement of phages in the control of CFU concentration.

The results of the most extensive of these experiments, begun on June 7, 1990, shall be presented. Unfortunately, the development of CFU and CFU(1), as in other experiments of 1990, was rather untypical in that, after the initial increase from $2.8 \times 10^{4}$ to $19.2 \times 10^{4} \mathrm{CFU} \mathrm{m}{ }^{-1}$, a reduction to $2.5 \times 10^{4} \mathrm{CFU} \mathrm{ml}{ }^{-1}$ between 1 and 2 days of incubation was observed only in regard to CFU. Until the 6th day of incubation the CFU concentration increased from $2.5 \times 10^{4}$ to $3.8 \times 10^{4} \mathrm{CFU} \mathrm{ml}{ }^{-1}$. With $\mathrm{CFU}(1)$ the findings were still more exceptional: Following a rapid increase by factor 25 during the first 24 hours of incubation, no significant change in concentration occurred until the end of the experiment. Similar to CFU, between 1 and 6 days of incubation there was further, if only minor, increase in CFU(l) from $8 \times 10^{3}$ to $15 \times 10^{3} \mathrm{ml}^{-1}$.

Initially, the inhibitory actions of bacteria towards each other were tested with 80 isolates derived from freshly collected seawater, using the spot-test method. A great variety in the appearance of inhibition zones as well as in regard to the numbers of isolates prone to inhibition was observed. Inhibition zones were distinguished according to clearness and sharpness of the edge, with several subclasses between the extremes, represented by wide, totally clear and sharp edged zones on the one hand, and by wide turbid zones without a clear-cut edge on the other. Five isolates of high, but different inhibitory potency were used in the tests of bacterial isolates derived from a darkened RSW sample by platings performed after 1 to 6 days of incubation. The results are compiled in Table 5.

Simultaneously, the bacteria were tested for phage sensitivity by using cell-free preparations (CFP) prepared directly from the RSW sample mentioned above and from sub-cultures set-up from this sample after 1 to 7 days of incubation, respectively. Subcultures were prepared by adding $0.5 \mathrm{ml}$ of RSW sample to $9.5 \mathrm{ml} \mathrm{SWB} / 5$ and subsequent incubation for 24 hours at $1 \mathrm{rpm}$. In addition, CFP prepared from two parallel samples were used, one of them inoculated with 3 strains of test phage and the other enriched with nutrients corresponding to their concentrations in SWB/5. The results of these tests are presented in Table 6.

From the findings compiled in Table 5 it cannot be deduced that changes in composition of the bacterial community during the early phase of incubation were caused by inhibitory or killing substances released by bacteria such as the test strains. Rather it seems likely that these changes were due to different generations times, and that bactericidal products of bacteria, if at all, had some effect in the long run.

Similar observations were made in regard to bacteriophages (Table 6). Only negligible changes in the percentage of isolates sensitive to phages present in CFP prepared from untreated RSW were found after 1 and 2 days of RSW incubation. The decrease in the percentage of phage sensitives among the bacteria isolated after 3 to 6 days of RSW incubation occurred too late to be helpful in explaining the decrease in CFU between 24 and 48 hours. (The other results compiled in Table 6 will be discussed later.)

Finally, the negative results of experiments concerning heterotrophic flagellates must be mentioned. For determining flagellate concentrations, only Petroff-Hauser counting chambers could be employed which in this case certainly was an unsatisfactory method. Under the experimental conditions tested - the same as employed in phage- 
Table 5. Occurrence (in \%) of bacteria, CFU (1), in darkened RSW of June 6, 1990, sensitive to inhibition by five bacterial test strains of different activity in dependence of duration of RSW incubation at $20^{\circ} \mathrm{C}$. Inhibition zone: $\mathrm{C}=$ clear with sharp edge, $\mathrm{T}=$ turbid. $\mathrm{N} 1 / \mathrm{N} 2=$ number of bacterial isolates tested/number of reliable results

\begin{tabular}{|c|c|c|c|c|c|c|c|c|}
\hline \multirow{2}{*}{$\begin{array}{l}\text { Test } \\
\text { strain }\end{array}$} & \multirow{2}{*}{$\begin{array}{l}\text { Inhibit. } \\
\text { zone }\end{array}$} & \multicolumn{7}{|c|}{ Incubation of RSW (days) } \\
\hline & & 0 & 1 & 2 & 3 & 4 & 5 & 6 \\
\hline \multirow{3}{*}{13} & $\mathrm{C}$ & 19.5 & 0 & 0 & 2.6 & 13.1 & 2.9 & 0 \\
\hline & $\mathrm{T}$ & 13.0 & 0 & 5.1 & 15.8 & 13.1 & 34.3 & 50.0 \\
\hline & - & 76.5 & 100 & 94.9 & 81.6 & 73.7 & 62.9 & 50.0 \\
\hline \multirow{3}{*}{37} & C & 61.0 & 100 & 97.4 & 85.8 & 69.7 & 74.3 & 81.3 \\
\hline & $\mathrm{T}$ & 23.4 & 0 & 2.6 & 3.9 & 13.1 & 8.6 & 12.5 \\
\hline & - & 15.6 & 0 & 0 & 10.5 & 17.1 & 17.1 & 6.6 \\
\hline \multirow{3}{*}{40} & $\mathrm{C}$ & 19.5 & 68.2 & 57.7 & 51.3 & 35.3 & 25.7 & 18.8 \\
\hline & $\mathrm{T}$ & 9.1 & 0 & 1.3 & 2.6 & 2.6 & 0 & 0 \\
\hline & - & 71.4 & 31.8 & 41.0 & 46.1 & 61.8 & 74.3 & 75.0 \\
\hline \multirow{3}{*}{52} & C & 64.9 & 86.4 & 76.9 & 73.7 & 55.3 & 62.9 & 50.0 \\
\hline & $\mathrm{T}$ & 31.2 & 0 & 2.6 & 2.6 & 6.6 & 5.7 & 12.5 \\
\hline & - & 3.9 & 13.6 & 20.5 & 23.7 & 38.2 & 31.4 & 37.5 \\
\hline \multirow{3}{*}{66} & $\mathrm{C}$ & 20.8 & 13.6 & 16.7 & 9.2 & 3.9 & 5.7 & 0 \\
\hline & $\mathrm{T}$ & 42.9 & 13.6 & 24.4 & 39.5 & 43.4 & 30.0 & 62.5 \\
\hline & - & 36.4 & 72.7 & 59.0 & 51.3 & 52.6 & 54.3 & 37.5 \\
\hline N1/N2 & & $80 / 77$ & $22 / 22$ & $79 / 78$ & $80 / 76$ & $82 / 76$ & $38 / 35$ & $16 / 16$ \\
\hline
\end{tabular}

survival experiments as well as still and roll culture ( $1 \mathrm{rpm})$ of RSW enriched with $25 \times$ SWB to nutrient concentration corresponding to SWB/10 - flagellates never reached the minimum concentration necessary for their observation by means of the counting chamber. In contrast, bacteriovorous flagellates grew profusely in corresponding cultures incubated at $18^{\circ} \mathrm{C}$ and 200 strokes $\min ^{-1}$ on a shaking table.

\section{DISCUSSION}

The main purpose of this investigation was to gain insight into processes controlling the survival of marine phage-host systems under natural conditions. Therefore, emphasis was placed on the role of bacteria which in some way play a pivotal role in phage survival. Other organisms such as phytoplankters must be expected to be important, at least indirectly. This was exemplarily demonstrated by the recent paper of Bratbak et al. (1990) who observed the successive development of planktonic algae, bacteria and phage as well as flagellates.

Unfortunately, the present investigation was abruptly halted for reasons of health and will not be resumed. To make reasonable use of phage-host systems (PHS) gathered during the course of this investigation, it was decided, in late summer of 1990, to collect preliminary data concerning PFU concentrations in the waters around Helgoland (Moebus, 1992a). On the grounds of the promising results of those tests, the latter type of work proceeded throughout 1991 (Moebus, 1992b). 
Table 6. Occurrence (in \%) of phage-sensitive bacteria, CFU (1), in darkened RSW of June 6, 1990, depending on duration of RSW incubation at $20^{\circ} \mathrm{C}$. Bacteria tested with cell-free preparations (CFP), containing unknown numbers of different phage strains, and with lysate of test phage H7/2. N1/N2 $=$ number of isolates tested/number of reliable results

\begin{tabular}{|c|c|c|c|c|c|c|c|}
\hline \multirow{2}{*}{$\begin{array}{l}\text { Origin } \\
\text { of CFP }\end{array}$} & \multirow{2}{*}{$\begin{array}{l}\text { CFP } \\
\text { of day }\end{array}$} & \multicolumn{6}{|c|}{ Incubation of RSW (days) } \\
\hline & & 1 & 2 & 3 & 4 & 5 & 6 \\
\hline \multirow{7}{*}{$\begin{array}{l}\text { (1) RSW } \\
\text { without } \\
\text { additions }\end{array}$} & 1 & 4.5 & 14.1 & 1.8 & 5.9 & 3.7 & 6.7 \\
\hline & 2 & 18.2 & 17.9 & 12.3 & 5.9 & 0 & 20.0 \\
\hline & 3 & 13.6 & 15.4 & 3.5 & 5.9 & 3.7 & 6.7 \\
\hline & 4 & 18.2 & 14.1 & 1.8 & 7.4 & 3.7 & 0 \\
\hline & 5 & 13.6 & 15.4 & 5.3 & 4.4 & 3.7 & 0 \\
\hline & 6 & 18.2 & 10.3 & 3.5 & 5.9 & 3.7 & 0 \\
\hline & 7 & 13.6 & 14.1 & 1.8 & 7.4 & 3.7 & 0 \\
\hline \multirow{5}{*}{$\begin{array}{l}\text { Subculture } \\
\text { of (1) }\end{array}$} & 1 & 54.5 & 65.4 & 35.1 & 26.5 & 14.8 & 26.7 \\
\hline & 2 & 45.5 & 66.7 & 35.1 & 29.4 & 14.8 & 26.7 \\
\hline & 3 & 54.5 & 66.7 & 35.1 & 30.9 & 14.8 & 26.7 \\
\hline & $4^{*}$ & 22.7 & 26.9 & 14.0 & 16.2 & 3.7 & 6.7 \\
\hline & 5 & 40.9 & 37.2 & 29.8 & 20.6 & 14.8 & 26.7 \\
\hline \multirow{9}{*}{$\begin{array}{l}\text { (2) RSW } \\
\text { with } 3 \\
\text { test } \\
\text { phages } \\
\text { added }\end{array}$} & 6 & 40.9 & 38.5 & 33.3 & 25.0 & 14.8 & 26.7 \\
\hline & 7 & 40.9 & 51.3 & 29.8 & 19.1 & 14.8 & 26.7 \\
\hline & 1 & 31.8 & 34.6 & 19.3 & 23.5 & 7.4 & 6.7 \\
\hline & 2 & 40.9 & 30.8 & 14.0 & 20.6 & 14.8 & 6.7 \\
\hline & 3 & 31.8 & 33.3 & 19.3 & 20.6 & 7.4 & 6.7 \\
\hline & 4 & 22.7 & 29.5 & 12.3 & 20.6 & 7.4 & 6.7 \\
\hline & 5 & 31.8 & 29.5 & 12.3 & 14.7 & 7.4 & 6.7 \\
\hline & 6 & 36.4 & 28.2 & 12.3 & 17.6 & 11.1 & 13.3 \\
\hline & 7 & 31.8 & 25.6 & 12.3 & 20.6 & 3.7 & 13.3 \\
\hline \multirow{4}{*}{$\begin{array}{l}\text { (3) RSW, } \\
\text { nutrients } \\
\text { added }\end{array}$} & 1 & 72.7 & 69.2 & 42.1 & 29.4 & 11.1 & 20.0 \\
\hline & 2 & 90.9 & 73.1 & 64.9 & 39.7 & 18.5 & 33.3 \\
\hline & 3 & 81.8 & 74.4 & 59.6 & 35.3 & 14.8 & 33.3 \\
\hline & 4 & 90.9 & 74.4 & 59.6 & 33.8 & 11.1 & 33.3 \\
\hline Lysate & $\mathrm{H} 7 / 2$ & 45.5 & 65.4 & 31.6 & 29.4 & 11.1 & 33.3 \\
\hline N1/N2 & & $22 / 22$ & $79 / 78$ & $80 / 57$ & $82 / 68$ & $38 / 27$ & $16 / 15$ \\
\hline
\end{tabular}

Although the findings presented in this paper provide no proof for the one or the other mechanism by which indigenous bacteria may negatively influence the infectiousness of marine phages, there seems to be little doubt that they are, in this respect, the most important organisms. Regarding their positive role in relation to the maintenance of PHS, observations made during this investigations are in agreement with those reported by Moebus (1992b): seawater generally is a poor medium for bacteriophage propagation.

This is demonstrated by the data compiled in Table 6 . Even in the presence of the slight nutrient enrichment coming along with inoculated test phage, the percentage of phage-sensitive bacteria increased by factor 2 to 3, as compared to plain RSW. With cellfree preparations (CFP) produced from samples with the higher nutrient concentrations 
an even stronger increase in the percentage of phage-indicating bacteria was found. These findings indicate that in RSW, at least, fewer phage strains were sufficiently reproduced to be detectable in CFP by the spot test employed. However, they may also be influenced by insufficient growth of lysogenic bacteria in plain RSW which failed to release phage able to induce virulent phage reproduction in the types of bacteria tested.

As also indicated in Table 6, special importance must be ascribed to bacteria sensitive to $H 7 / 2$, as they were the only ones which, with varying and often considerable portions, were found in almost any of the seawater samples used. Correspondingly, in fresh RSW PFU were detected far more often, even if only in low numbers, with the host bacteria $\mathrm{H} 7$ and $\mathrm{H} 71$ than with any of the other hosts. (More details on this aspect are presented by Moebus, 1992b.)

Large portions of bacteria sensitive to $\mathrm{H} 7 / 2$ were found to be prone to inhibition. In preliminary investigations it was found that such bacteria, depending on strain specificities as well as on nutrient concentration, profoundly influence the concentration of surviving H7/2-PFU. Besides this, with sensitive bacteria capable of reproducing phage $\mathrm{H} 7 / 2$, this phage seems, under certain circumstances, to enter into a relationship resembling pseudolysogeny.

Although the reasons for the loss of infectivity of free phage particles in seawater essentially remain unknown, the especially high sensitivity of phage strains $\mathrm{H} 7 / 2$ and H17/1 may serve as a clue. The capsid of H17/1 particles by Frank \& Moebus (1987) was found to be composed of 2 to 3 layers, the fragility of which probably being the reason for the uniquely low lysate stability of this phage among the many strains, including four different phages infective for host $\mathrm{H17}$, in the collection of the present author. In the same paper, virions of phage $\mathrm{H} 7 / 2$ were also reported to have an unusually complex, though completely different structure. Possibly this structural complexity makes these two phage strains more sensitive to attacks of proteolytic enzymes than more simply built virions. Proteases, including bacterial ones, have been shown to degrade enteroviruses (Cliver \& Herrmann, 1972; Herrmann \& Cliver, 1973), which varied greatly in their sensitivity to the same enzymes. Other findings indicate that proteases may not be the primarily inactivating factor (Toranzo et al., 1983).

Bergh et al. (1989) and Proctor \& Fuhrman (1990) reported for marine waters concentrations as high as $10^{7} \mathrm{ml}^{-1}$ of viral particles, contradicting information on bacteriophage concentrations in off-shore environments in the range of 0 to $10 \mathrm{PFU} \mathrm{ml} \mathrm{m}^{-1}$ (Spencer, 1960), available until then. Although the omnipresence of marine phages in tested environments was demonstrated by investigations performed in the following two decades, no attempts were made until recently to solve the enigma of bacteriophages surviving at the extremely low concentrations supposed.

Electron microscopic investigations of Borsheim et al. (1990), Bratbak et al. (1990), and Heldal \& Bratbak (1991) provided information on changes in the concentration of viral particles in the environments tested which, in a first approximation, can be assumed to represent the survival rates of the viral communities encountered. The survival rates calculated by these authors are generally considerably lower than those reported in the present publication. Several reasons for this difference are imaginable.

The most important reason assumedly is that the above mentioned authors, observed whole microbial populations either under natural conditions or kept in large enclosures for only a short time, while this investigation is concerned with the influence of only 
partially recordable microbial communities, developing in small volumes, on arbitrarily introduced virulent bacteriophages. This handicap, however, does not exist in regard to the survival rates recently reported by Moebus (1992b) which are based on observations of natural populations of virulent phage occurring in the waters around Helgoland. These "natural" survival rates compare more favourably with the "artificial" ones reported in this paper than with the lower rates based on electron microscopic observations. Any attempt to explain these differences (e.g. with a predominant role of temperate phage) would be plain speculation as long as nothing more than shape and size is known of the viral particles seen in the electron microscope.

Acknowledgements. The author is very grateful to $C$. Berger for taking the pains to correct his English, and to G. Hennemann for preparing ready-for-print copies of drawings, in this and two preceeding papers published in this journal. Thanks are also due to $\mathrm{A}$. Werner who was involved in part of the experiments done in 1988.

\section{LITERATURE CITED}

Adams, M. H., 1959. Bacteriophages. Interscience Publ., New York, 592 pp.

Ahrens, R., 1971. Untersuchungen zur Verbreitung von Phagen der Gattung Agrobacterium in der Ostsee. - Kieler Meeresforsch. 27, 102-112.

Akin, E. W., Hill, W. F., Cline, G. B. \& Benton, W. H., 1976. The loss of poliovirus I infectivity in marine waters. - Wat. Res. 10,59-63.

Bergh, O., Borsheim, K. Y., Bratbak, G. \& Heldal, M., 1989. High abundance of viruses found in aquatic environments. - Nature, Lond. 340, 467-468.

Berry, S. A. \& Noton, B. G., 1976. Survival of bacteriophages in seawater. - Wat. Res. 10, 323-327.

Bitton, G. \& Mitchell, R., 1974. Effects of colloids on the survival of bacteriophages in seawater. Wat. Res. 8, 227-229.

Borsheim, K. Y., Bratbak, G. \& Heldal, M., 1990. Enumeration and biomass estimation of planktonic bacteria and viruses by transmission electron microscopy. - Appl. environ. Microbiol. 56, $352-356$.

Bratbak, G., Heldal, M., Norland, S. \& Thingstad, F., 1990. Viruses as partners in spring bloom microbial trophodynamics. - Appl. environ. Microbiol. 56, 1400-1405.

Cliver, D. O. \& Herrmann, J. E., 1972. Proteolytic and microbial inactivation of enteroviruses. - Wat. Res. 6, 797-805.

Frank, H. \& Moebus, K., 1987. An electron microscopic study of bacteriophages from marine waters. - Helgoländer Meeresunters. 41, 385-414.

Fujioka, R. S., Loh, P. H. \& Lau, L. S., 1980. Survival of human enteroviruses in the Hawaiian ocean environment: evidence for virus-inactivating microorganisms. - Appl. environ. Microbiol. 39, 1105-1110.

Gundersen, K., Brandberg, A., Magnusson, S. \& Lycke, E., 1967. Characterization of a marine bacterium associated with virus inactivating capacity. - Acta path. microbiol. scand. 71, 281-286.

Heldal, M. \& Bratbak, G., 1991. Production and decay of viruses in aquatic environments. - Mar. Ecol. Prog. Ser. 72, 205-212.

Herrmann, J. E. \& Cliver, D. O., 1973. Degradation of Coxsackie type A9 by proteolytic enzymes. Infect. Immun. 7, 513-517.

Hidaka, T. \& Ichida, K., 1972. On the undesirable effects of filtration through membrane filters on some marine bacteriophages. - Mem. Fac. Fish., Kagoshima Univ. 21, 97-102.

Hoyt, P. R. \& Sizemore, R. K., 1982. Competitive dominance by a bacteriocin-producing Vibrio harveyi strain. - Appl. environ. Microbiol. 44, 653-658.

Kamei, Y., Yoshimizu, M., Ezura, Y. \& Kimura, T., 1987. Screening of bacteria with antiviral activity against infectious hematopoietic necrosis virus (IHNV) from estuarine and marine environments. - Bull. Jap. Soc. scient. Fish. 53, 2179-2185. 
Kapuscinski, R. B. \& Mitchell, R., 1980. Processes controlling virus inactivation in coastal waters. Wat. Res. 14, 363-371.

Kapuscinski, R. B. \& Mitchell, R., 1983. Sunlight-induced mortality of viruses and Escherichia coli in coastal seawater. - Environ. Sci. Technol. 17, 1-6.

Kott, Y., 1966. Survival of T bacteriophages and coliform bacteria in sea water. - Publ. Inst. mar. Sci., Tex. 11, 1-6.

Kott, Y. \& Ben Ari, H., 1968. Bacteriophages as marine pollution indicators. - Rev. int. Oceanogr. méd. 9, 207-217.

Magnusson, S., Gunderson, K., Brandberg, A. \& Lycke, E., 1967. Marine bacteria and their possible relation to the virus inactivating capacity of sea water. - Acta path. microbiol. scand. 71, 274-280.

Mitchell, R. \& Jannasch, H. W., 1969. Processes controlling virus inactivation in seawater. - Environ. Sci. Technol. 3, 941-943.

Moebus, K., 1992a. Preliminary observations on the concentration of marine bacteriophages in the water around Helgoland. - Helgoländer Meeresunters. 45, 411-422.

Moebus, K., 1992b. Further investigations on the concentration of marine bacteriophages in the water around Helgoland, with reference to the phage-host systems encountered. - Helgoländer Meeresunters. 46, 275-292.

Niemi, M., 1976. Survival of Escherichia coli phage T7 in different water types. - Wat. Res. 10, 751-755.

Oppenheimer, C. H. \& ZoBell, C. E., 1952. The growth and viability of sixty-three species of marine bacteria as influenced by hydrostatic pressure. - J. mar. Res. 11, 10-18.

Proctor, L. M. \& Fuhrman, J. A., 1990. Viral mortality of marine bacteria and cyanobacteria. - Nature, Lond. 343,60-62.

Spencer, R., 1955. A marine bacteriophage. - Nature, Lond. 175, 690.

Spencer, R., 1960. Indigenous marine bacteriophages. - J. Bact. 79, 614 .

Toranzo, A. E., Barja, J. L. \& Hetrick, F. M., 1982. Antiviral activity of antibiotic-.producing marine bacteria. - Can. J. Microbiol. 28, 231-238.

Toranzo, A. E., Barja, J. L. \& Hetrick, F. M., 1983. Mechanism of poliovirus inactivation by cell-free filtrates of marine bacteria. - Can. J. Microbiol. 29, 1481-1486.

Ward, R. L., Knowlton, D. R. \& Winston, P. E., 1986. Mechanism of inactivation of enteric viruses in fresh water. - Appl. environ. Microbiol. 52, 450-459.

Zachary, A., 1976. Physiology and ecology of bacteriophages of the marine bacterium Beneckea natriegens: salinity. - Appl. environ. Microbiol. 31, 415-422. 